\title{
Effect of Organic Waste on Crystal Structure and Mechanical Properties of Concrete
}

\author{
Samuel Oloruntoba Olugbenga Olusunle, Theresa Chikwuo Ezenwafor, \\ Bidemi Sikirat Jiddah-Kazeem, Akeem Kareem, Ojo Jeremiah Akinribide, \\ Adekunle Taofeek Oyelami \\ Engineering Materials Development Institute, Akure, Nigeria \\ Email: tolusunle@yahoo.co.uk
}

Received 10 July 2015; accepted 26 September 2015; published 29 September 2015

Copyright (C) 2015 by authors and Scientific Research Publishing Inc.

This work is licensed under the Creative Commons Attribution International License (CC BY). http://creativecommons.org/licenses/by/4.0/

(c) (i) Open Access

\begin{abstract}
The influence of organic waste as an additive to concrete formulation has been studied by replacing up to $10 \%$ of cement ratio with locally sourced organic additive. The reference cement used was Portland cement; three different organic wastes were used in the mixture: periwinkle shell, extracted silica from corn hob ash and coconut shell ash. Uniform distribution of the additive was ensured by thorough mixing prior to water addition. Casting and curing of the concrete were done in line with established standard. The compressive strength test was carried out using the Instron universal testing machine and the oxides of elemental composition of the cement and the additives were determined using EDXRF Spectrometer (EDX 3600B) while the crystallography studies were carried out using EMMA) X-ray diffractometer . The result obtained indicated that there was a significant difference between the value of density, packing efficiency and compressive strength of each reinforced concrete with that of the reference cement which was attributable to the presence of additives. The cement formulation with silica as admixture was found to have the highest compressive strength of $217.94 \mathrm{MPa}$, while the reference cement had the lowest compressive strength of 81.45 MPa. This study has established that locally sourced organic additives (emerging additives), influence the mechanical properties of concretes.
\end{abstract}

\section{Keywords}

High Strength Concrete (HSC), Organic Waste, Compressive Strength, Elemental Characterization

\section{Introduction}

The strength of concrete determines its area of applications; therefore efforts to ascertain this vital parameter cannot be over emphasized. This becomes more important when high specific properties are desired. Hence in

How to cite this paper: Olusunle, S.O.O., Ezenwafor, T.C., Jiddah-Kazeem, B.S., Kareem, A., Akinribide, O.J. and Oyelami, A.T. (2015) Effect of Organic Waste on Crystal Structure and Mechanical Properties of Concrete. Journal of Minerals and Materials Characterization and Engineering, 3, 427-434. http://dx.doi.org/10.4236/jmmce.2015.35045 
concrete design and quality control, strength and other properties of interest are generally specified and in line with the intended area of application. Though conventional concretes have good fire resistance, high compressive strength with least corrosion rate; it is weak in tension due to cracking, creep and shrinkage. The compressive strength however, has been noted as the most essential parameter in concrete structural design; these parameters are rarely consistent as it varies with additive that is often introduced to modify and/or reduce cost of the production of concrete [1]. Other mechanical properties of interest with respect to concrete, among others are energy at break and modulus of elasticity.

As the need to ascertain concrete properties is increasing, so does the need to establish the determinant of these properties. For example, a number of benefits were derived through reinforcing cement with additives [2]. The improvements recorded were in the light of increased compressive strength of concrete, reduced cement content for specific target and at equal strength, thus saving cost of cement and by extension of the overall concrete. Moreover, durability and workability are also increased. Hence proper choice of suitable additive alongside other parameters (cement type, w/cm ratio, aggregate type and grading, mineral admixtures, chemical additives, curing conditions and age of concrete etc.) that influence the strength of HSC, produces sound concretes that are most suitable for a given application. Even though the use of chemical additives is vital to concrete formulation, their cost however, is so high that their usage is limited to only when they become unavoidable as in the case of high-rise buildings, building superstructures of long-span bridges and so on [1]. However, the use of organic additive proves to be promising especially that they are tagged as "environmental waste".

HSC has been produced using this emerging additive and widely used in the US and Europe [1]. However, intensive researches geared at establishing the full potential of organic additives as well as the influence of synthetic additives in reinforced concrete are on the increase in the laboratories across the globe according to [3]-[5]. Among the successes recorded through these researches involving organic waste as an additive are superior properties due to addition of silica (extracted from corn hob ash). This silica contains silicon oxide and is basically is pozzolanic or both pozzolanic and cementious to a degree. The silica when added during grinding process modifies the surface of the cement particles and as a consequence promotes the formation of highly reactive amorphous structure. It also acts as microfiller and participates in pozzolanic reactions, thus having a net effect in the properties and performance of the reinforced cement [6]. This can be attested from result obtained (under laboratory conditions) when concrete mixed with organic wastes produced a compressive strength in excess of $180 \mathrm{MPa}$; and this is far beyond some prime of compressive stress of approximately $125 \mathrm{MPa}$ experienced in some tall buildings [7]. Similarly, [8] in his studies of the permeability and resistance to sulphate attack and alkali-aggregate reactivity of Portland cement found that the concrete paste mixed with the silica exhibited higher strength than the conventional one. Moreover, [8] documented a test where 16\% and 25\% of cement used in the paste and mortar, measured by mass, was replaced by silica fume additives (SF). Their results showed that the partial replacement of cement by SF increased the compressive strength of mortar. [9] studied the effect of replacing cement by flying ash (FA) and SF with different w/c ratios of 0.30, 0.40 and 0.50 . They noticed that FA improved the post peak compressive behaviour. [10] stated that the addition of 15\% pozzolan and $15 \%$ SF to concrete resulted in a 26\% increase of the 28-day compressive strength of concrete. For mixes with a w/cm ratio of 0.35 , the strength of the SF concrete was found to be higher than the strength of the concretes without SF.

In line with the aforementioned potentials of organic additives (such as periwinkle shells, extracted silica from corn hob, coconut shell ash etc.) in enhancing the properties of concrete to suite intended application and the abundance of these additives (often considered as waste) in Nigeria, the present research is projected at exploring the possibilities of producing HSC that is resistant to sulphate attack and alkali-aggregate reactivity using organic based additives sourced locally. This will go in a long way at conserving foreign exchange, improved job opportunities coupled with clean and secured environment in one hand; while at the same time producing sound and reliable concrete at reduced cost.

\section{Material and Method}

\subsection{Materials Selections, Mixing and Casting of the Concrete}

In the course of this research, ordinary Portland cement type I, conforming to ASTM C150 was used. The additives used include: coconut shell ash (CSA), periwinkle shell (PWK) and extracted silica (from corn hob ash). The cement (CEM) used for the study represents the most predominantly used in the country. Each of the dried mate- 
rials was crushed and ball milled with 9VS model to smaller particle size in order to enhance homogeneity. The sample was sieved using an Octagon Digital sieve and the undersize of 150 micron of each sample was utilized.

Cement was replaced, by weight, with 10 percentages of each additive during dry mixing. Water needed for the mix was adjusted based on the absorption of aggregate. The concrete was mixed for about 7 minutes. During mixing, water was added to the mix incrementally to attain the consistency and slump required. The time, sequence and method of mixing the aggregates and additives for each sample remained unchanged. After mixing, the fresh concrete was casted in a mould. Specimens were allowed to set inside the mould at a temperature of about $25^{\circ} \mathrm{C}$ in the laboratory for 24 hours, and then finally cured under atmospheric conditions for 5 days.

\subsection{Elemental Characterization, Crystallography Study and Compression Strength Test the Concrete}

The oxides of elemental composition of the cement and the additives were determined using EDXRF Spectrometer (EDX 3600B).

The spectrum and data of the pure and reinforced concrete was obtained using Enhanced Mini-Materials Analyzer (EMMA) X-Ray diffractometer. The crystallography study was done using the software containing the data base supplied by the International Centre for Diffraction Data (ICDD).

The compression test was carried out on the test piece of each sample using Instron universal testing machine (Model 3369). For each specimen, the load was steadily applied until failure occurs. The average compressive strength was reported.

\section{Result and Discussion}

\subsection{Elemental Characterization}

The data and spectrum of metal oxide composition of the pure cement and the additives are presented in Table 1 and Figures 1(a)-(g) shows the EDX spectrum respectively. From the result obtained, it can be seen that pure concrete and periwinkle shell has almost the same value of calcium oxides of about $36 \%$. Apart from the extracted silica that gave $63 \%$ of $\mathrm{SO}_{2}$, the periwinkle and coconut shell ash have lowest content of silica of about $0.67 \%$ and $0.79 \%$ respectively. High content of Nickel oxide was observed in the XRF result of coconut shell ash and periwinkle contains highest content of calcium oxide respectively. An oxide of sulphur was high in the pure cement. The variations in the percentage compositions of the oxides of these elements in the additives especially $\mathrm{SiO}_{2}$ and $\mathrm{CaO}$ contribute to the variations in mechanical properties of reinforced concrete.

\subsection{Crystallography Study}

The XRD spectrum of pure and reinforced concrete is presented in Figures 2(a)-(d) while Table 2 shows the crystallographic data. The spectrum of the pure concrete showed several peaks at different diffraction angles but the introduction of the additives modified the spectrum. Moreover, the crystallographic data obtained (Table 2) indicates that the introduction of additives to concrete affects its crystal system. The bravais lattices of all the various formulations of cement used in this study were found to be of simple type. However, they belong to different crystal systems. Table 2 also presented the result of atomic packing factor (APF) and density $(\rho)$ of both the pure and reinforced concrete. The reference sample has APF of $45 \%$ and density of $3.54 \times 10^{-6}$ but these values changed after reinforcement with CEM $+\mathrm{SiO}_{2}$ having the highest value of APF $(68 \%)$ and $\rho\left(7.11 \times 10^{-2}\right)$ respectively. Literature has attested to the fact that the higher the value of the APF, the larger the volume of the unit cell being occupied by the atoms of the material in question, moreover, the larger the volume of the cell being occupied, the stronger and denser the material while the lower the value of APF, the weaker the material. From the obtained result, the APF of the analysed sample follows the trend; $\mathrm{CEM}+\mathrm{SiO}_{2}>\mathrm{CEM}+\mathrm{PWK}>$ $\mathrm{CEM}+\mathrm{CSA}>\mathrm{CEM}$ showing that $68 \%$ of $\mathrm{CEM}+\mathrm{SiO}_{2}$ atoms occupied the volume of the unit cell and $32 \%$ was left void/empty while the reference sample has largest void of $55 \%$ with only $45 \%$ of its particles occupying the cell volume. Hence, the strength of the material follows the above trend.

\subsection{Compression Strength of Reinforced Concrete}

Table 3 and Figure 3 show the variation of compressive strength of pure and reinforced concrete. Though the result shows that the compressive strength of all the reinforced concrete is higher against the value of $81.45 \mathrm{MPa}$ 


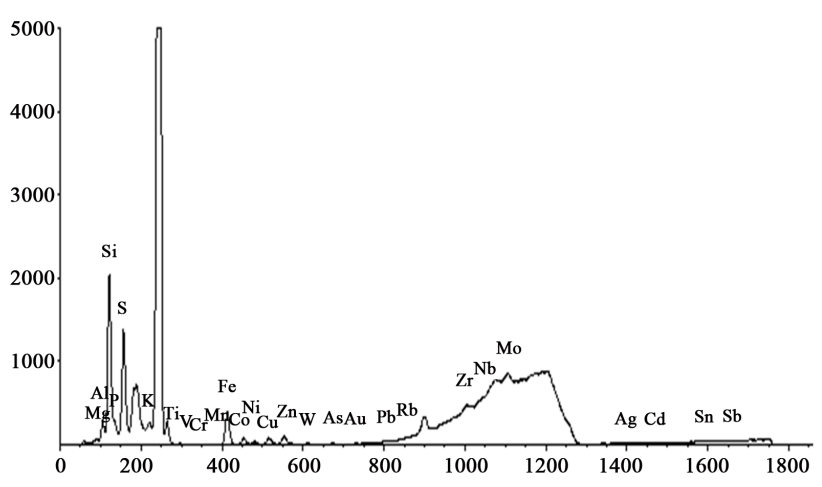

(a)

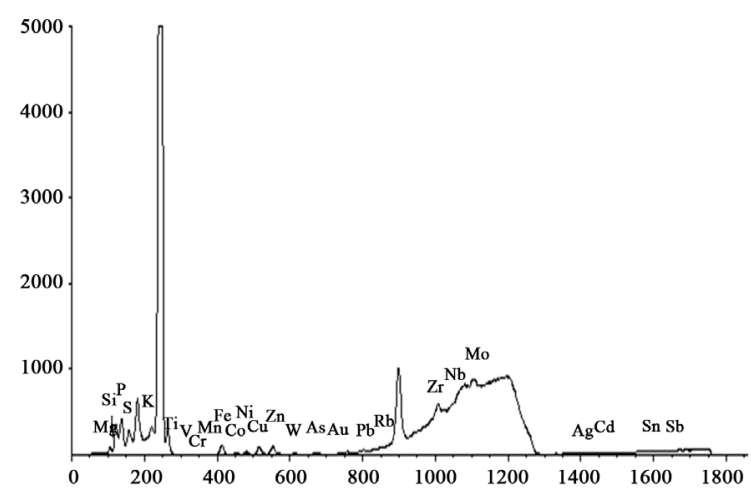

(b)

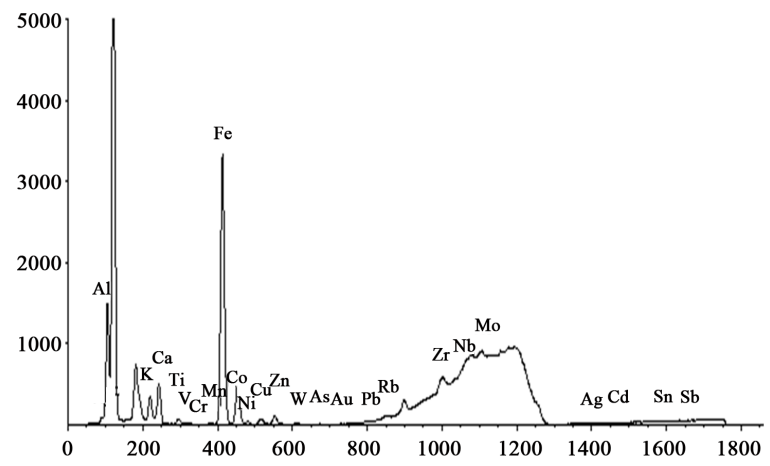

(d)

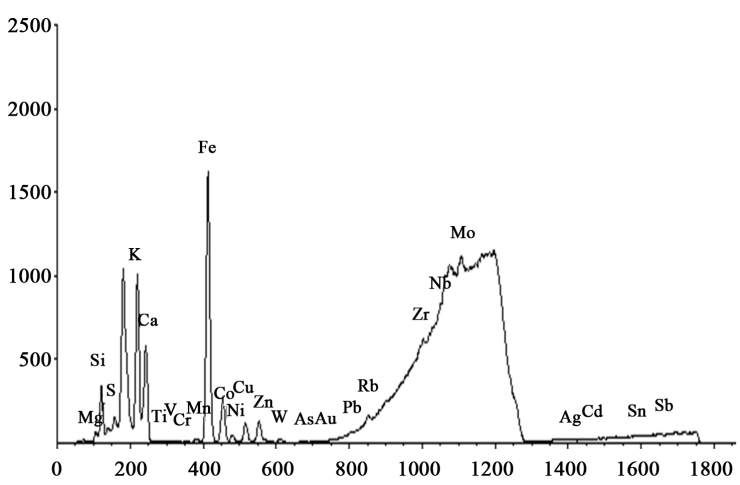

(f)

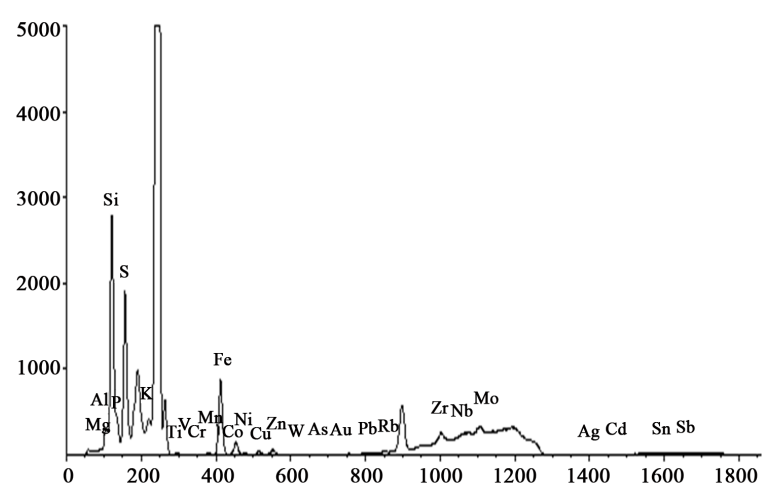

(c)

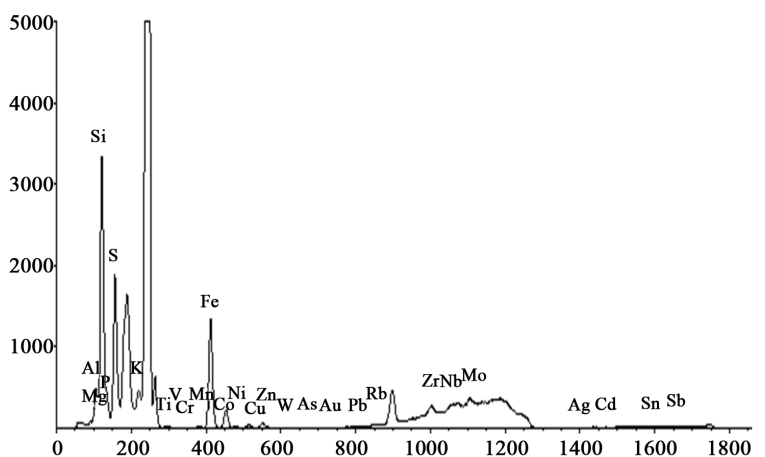

(e)

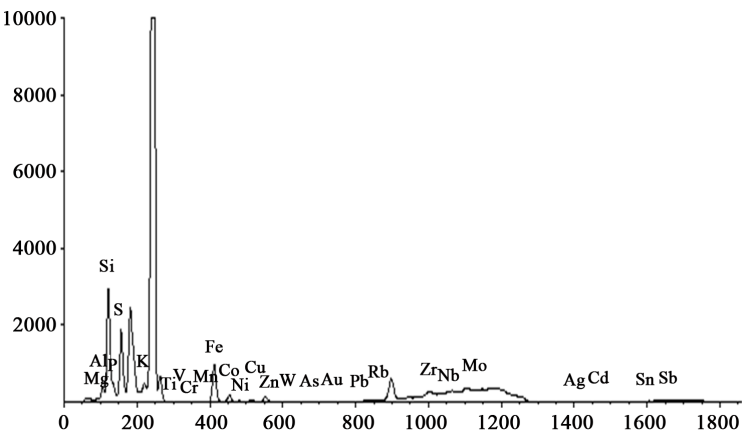

(g)

Figure 1. (a) EDX spectrum of CEM; (b) EDX spectrum of PWK; (c) EDX of PWK + CEM; (d) EDX spectrum $\mathrm{SiO}_{2}$; (e) EDX spectrum $\mathrm{SiO}_{2}+\mathrm{CEM}$; (f) EDX spectrum of CSA; (g) EDX spectrum of CSA + CEM. 


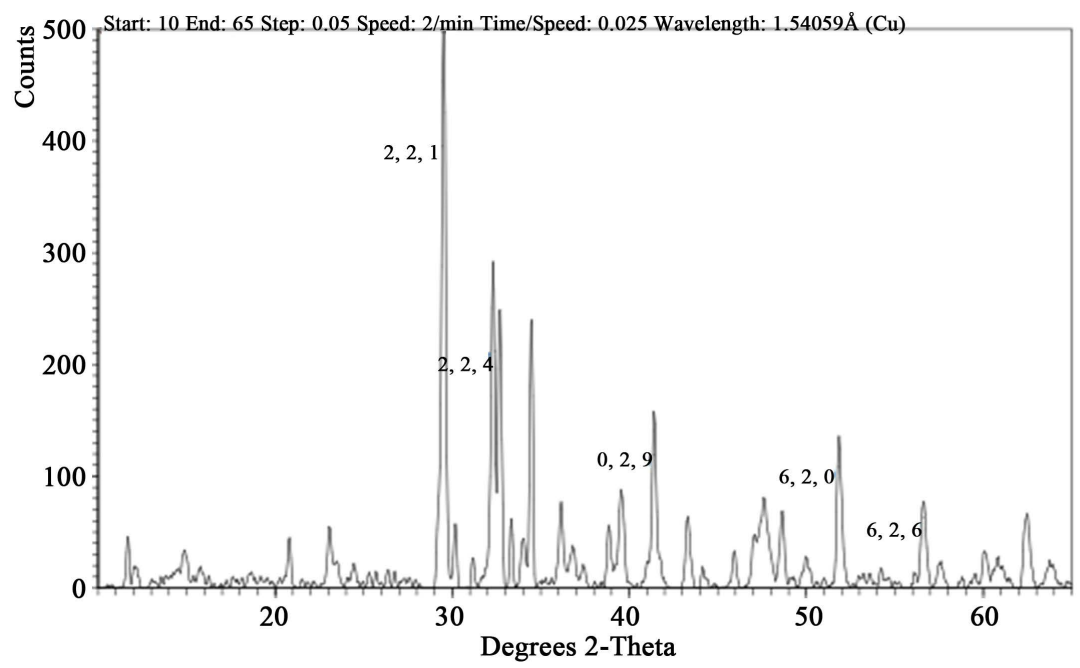

(a)

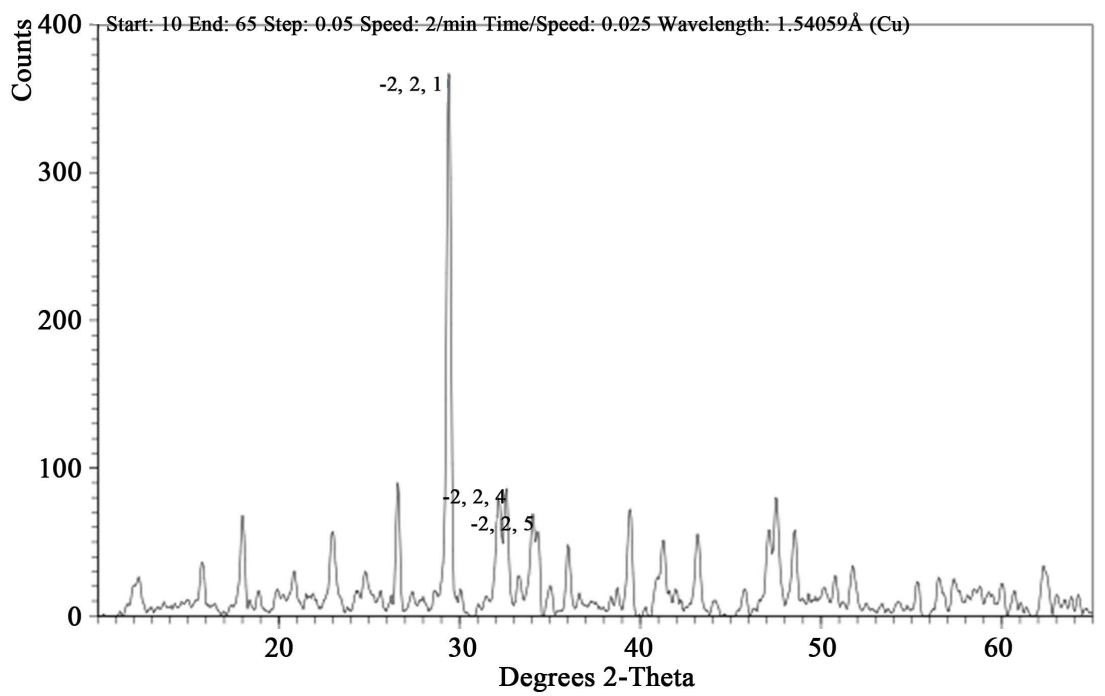

(b)

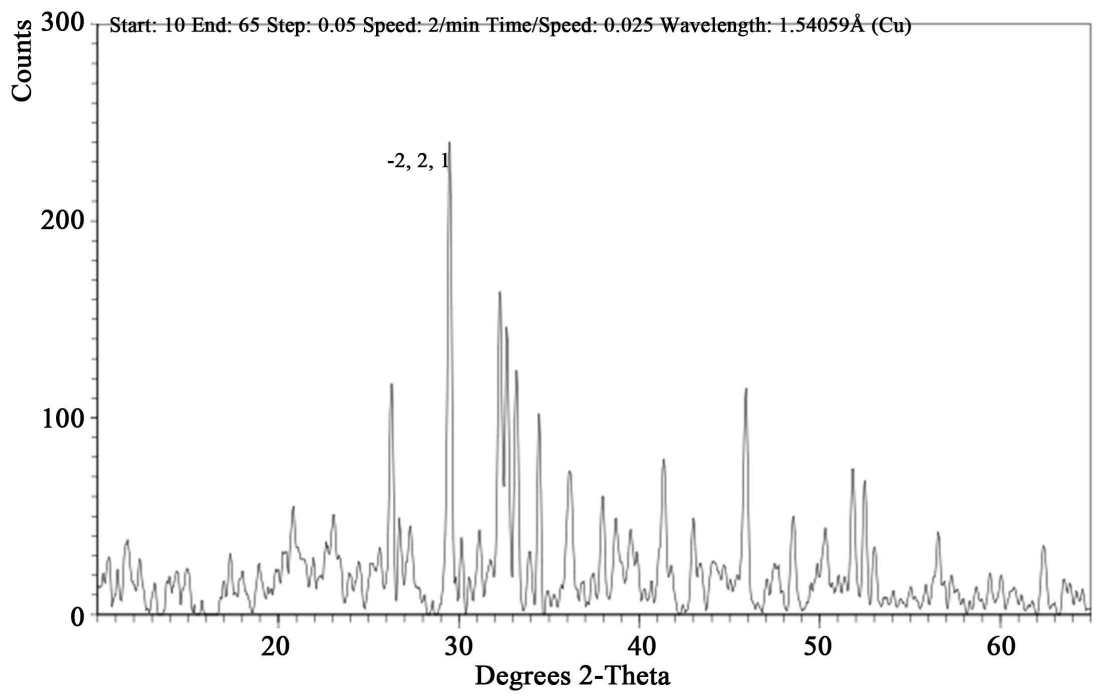

(c) 


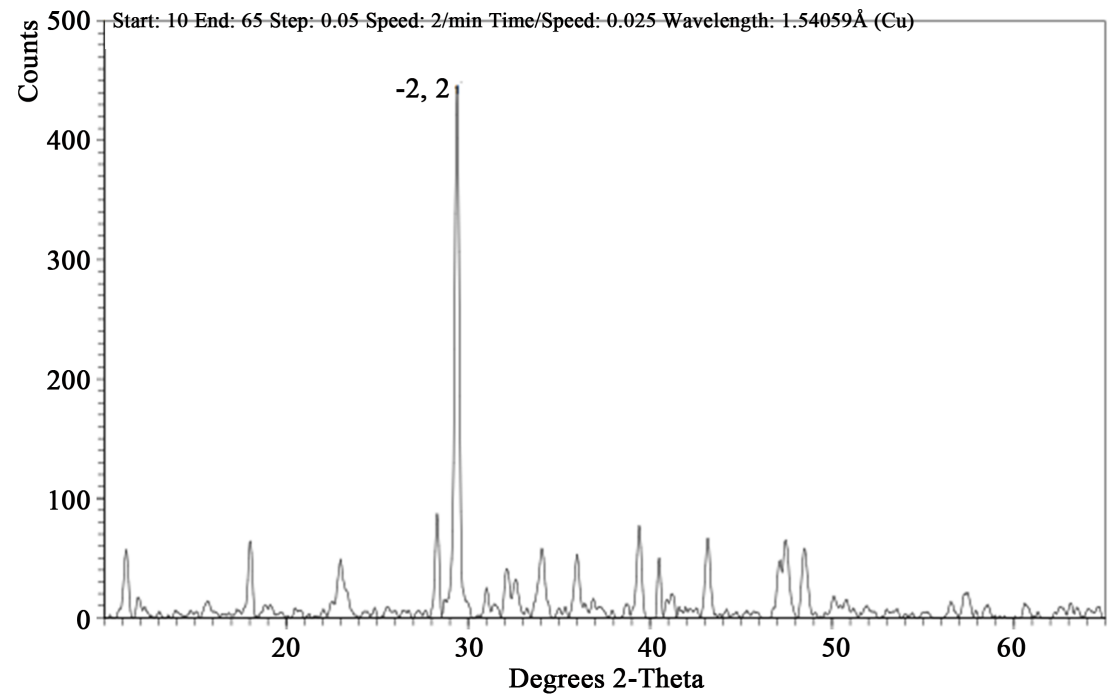

(d)

Figure 2. (a) XRD of CEM; (b) CEM + CSA; (c) CEM + PWK; (d) CEM + $\mathrm{SiO}_{2}$.

Table 1. The XRF result of elemental oxide composition of pure concrete and additives (\%).

\begin{tabular}{|c|c|c|c|c|}
\hline Elemental oxides & CEM & PWK & $\mathrm{SiO}_{2}$ & CSA \\
\hline MgO & 0.1758 & 0.0968 & 0.0000 & 0.0000 \\
\hline $\mathbf{A l}_{2} \mathbf{O}_{3}$ & 1.6875 & 0.4989 & 0.0056 & 0.4884 \\
\hline $\mathrm{SiO}_{2}$ & 3.9319 & 0.6743 & 53.8287 & 0.7928 \\
\hline $\mathbf{P}_{2} \mathbf{O}_{5}$ & 0.2650 & 0.4239 & 0.1854 & 0.1342 \\
\hline $\mathrm{SO}_{3}$ & 2.9771 & 0.7715 & 0.5713 & 0.5395 \\
\hline $\mathrm{K}_{2} \mathrm{O}$ & 0.0000 & 0.0503 & 0.0215 & 1.7468 \\
\hline $\mathrm{CaO}$ & 36.1396 & 36.3462 & 0.6759 & 0.2996 \\
\hline $\mathrm{TiO}_{2}$ & 0.0000 & 0.0000 & 0.0000 & 0.0000 \\
\hline $\mathbf{V}_{2} \mathbf{O}$ & 0.0053 & 0.0054 & 0.0074 & 0.0096 \\
\hline $\mathrm{Cr}_{2} \mathrm{O}_{3}$ & 0.0022 & 0.0025 & 0.0066 & 0.0094 \\
\hline MnO & 0.0064 & 0.0089 & 0.0208 & 0.0524 \\
\hline $\mathrm{Co}_{2} \mathrm{O}_{3}$ & 0.0038 & 0.0010 & 0.0106 & 0.0135 \\
\hline FeO & 0.9572 & 0.3535 & 1.9481 & 4.7631 \\
\hline $\mathrm{Ni}_{2} \mathrm{O}$ & 0.0508 & 0.0548 & 0.0694 & 0.0981 \\
\hline $\mathrm{CuO}$ & 0.0537 & 0.0719 & 0.0835 & 0.2378 \\
\hline $\mathrm{ZnO}$ & 0.0918 & 0.0936 & 0.1616 & 0.1550 \\
\hline AsO & 0.0000 & 0.0000 & 0.0000 & 0.0000 \\
\hline PbO & 0.0097 & 0.0091 & 0.0000 & 0.0006 \\
\hline $\mathbf{W}_{2} \mathbf{O}$ & 0.0722 & 0.1014 & 0.2231 & 0.2513 \\
\hline Au & 0.0000 & 0.0000 & 0.0000 & 0.0000 \\
\hline $\mathrm{Ag}_{2} \mathrm{O}$ & 0.0046 & 0.0070 & 0.0000 & 0.0044 \\
\hline $\mathbf{R b}$ & 0.0000 & 0.0000 & 0.0091 & 0.0038 \\
\hline
\end{tabular}

NB: $\mathrm{CEM}=$ Pure cement, $\mathrm{PWK}=$ Periwinkle, $\mathrm{SiO}_{2}=$ Extracted Silica, $\mathrm{CSA}=$ Coconut shell ash. 


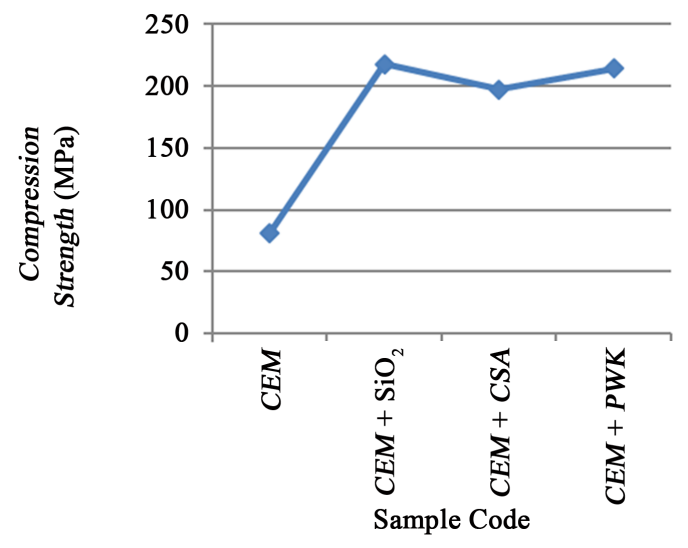

Figure 3. The graph of the compressive strength.

Table 2. Shows the crystallographic data for pure and reinforced concrete.

\begin{tabular}{cccccc}
\hline Sample code & $\begin{array}{c}\text { Chemical compositions } \\
\text { at the phases }\end{array}$ & Crystal system & Bravais lattice & $\begin{array}{c}\text { Atomic packing } \\
\text { factor (APF) or } \\
\text { packing efficiency (\%) }\end{array}$ & $\begin{array}{c}\text { Density } \\
\left(\mathrm{g} / \mathrm{cm}^{3}\right)\end{array}$ \\
\hline $\mathrm{CEM}$ & $\mathrm{Ca}_{3}\left(\mathrm{H}_{6} \mathrm{Si}_{2} \mathrm{O}_{7}\right) \mathrm{OH}$ & Monoclinic & Simple & 45 & $3.54 \times 10^{-6}$ \\
$\mathrm{CEM}+\mathrm{SiO}_{2}$ & $(\mathrm{MgFe})_{17} \mathrm{Si}_{20} \mathrm{O}_{54}(\mathrm{OH})_{6}$ & Orthorhombic & Simple & 68 & $7.11 \times 10^{-2}$ \\
$\mathrm{CEM}+\mathrm{CSA}$ & $\mathrm{Ca}_{3}\left(\mathrm{SiO}_{8}(\mathrm{OH})_{2}\right)$ & Triclinic & Simple & 52 & $7.01 \times 10^{-4}$ \\
$\mathrm{CEM}+\mathrm{PWK}$ & $\mathrm{CaSiO}_{3}$ & Monoclinic & Simple & 61 & $2.67 \times 10^{-3}$ \\
\hline
\end{tabular}

Table 3. Compressive strength.

\begin{tabular}{ccc}
\hline S/N & Sample code & Compression strength (MPa) \\
\hline $\mathbf{1}$ & $\mathrm{CEM}$ & 81.45 \\
$\mathbf{2}$ & $\mathrm{CEM}+\mathrm{SiO}_{2}$ & 217.94 \\
$\mathbf{3}$ & $\mathrm{CEM}+\mathrm{CSA}$ & 197.02 \\
$\mathbf{4}$ & $\mathrm{CEM}+\mathrm{PWK}$ & 213.99 \\
\hline
\end{tabular}

obtained for the control mix of the same quantity; CEM + $\mathrm{SiO}_{2}$ and CEM + PWK demonstrated a good value of compressive strength above $200 \mathrm{MPa}$. The improved in strength witnessed in $\mathrm{CEM}+\mathrm{SiO}_{2}$ is due to the crystallographic alteration that could be as a result of the addition of extracted silica in the matrix. It had earlier been reported that improved strength is attributed to the pozzolanic action of silica and densification of the concrete matrix [1]. The CEM + PWK also gave compression value of $213.99 \mathrm{MPa}$ and is ascribed to the high content of Calcium which though act as a binder, also improve the strength during curing process [11].

Generally, the investigation has indicated that the rate of strength gain is higher in reinforced concrete than in conventional concrete (Figure 3) using indigenous materials.

\section{Conclusions and Recommendation}

The value of hardness, atomic packing factor and density obtained signifies that $\mathrm{SiO}_{2}+\mathrm{CEM}$ have the best mechanical strength. The investigation established that reinforcing pure cement with additives especially extracted silica from corn hob and periwinkle shell would produce a concrete of high strength, thereby affirming the possibility of producing concrete of high strength that was cost effective, using indigenous materials as modifying agent.

It is recommended that further work be carried out to determine the optimal effect of other abundant indigenous organic wastes on concrete as well as investigate the optimal processing parameters like curing effect (void 
formation), particle sizes, and concentration variations of both the additives and concrete; this is important when standards are to be established using organic admixtures in cement.

\section{References}

[1] Ismeik, M. (2009) Effect of Mineral Admixtures on Mechanical Properties of High Strength Concrete Made with Locally Available Materials. Jordan Journal of Civil Engineering, 3.

[2] Langan, B.W., Weng, K. and Ward, M.A. (2002) Effect of Silica Fume and Fly Ash on Heat of Hydration of Portland Cement. Journal of Cement and Concrete Research, 32, 1045-1051. http://dx.doi.org/10.1016/S0008-8846(02)00742-1

[3] Batrakov, V.G. (1990) Modified Concrete. Stroyizdat, Moscow, 6-37.

[4] Ramachandran, V.S. (1995) Concrete Admixture Handbook. Noyes Publication, New Jersey.

[5] Olusunle, S.O.O., Ezenwafor, T.C., Jiddah-Kazeem, B.S., Kareem, A., Akinribide, O.J. and Oyelami, A.T. (2015) Evaluation of Effects of Synthetic Compound and Mineral Admixture on Crystal Structure of Concrete. Journal of Minerals and Materials Characterization and Engineering, 3, 134-141. http://dx.doi.org/10.4236/jmmce.2015.33016

[6] Sobolev, K. (2003) Effect of Complex Admixture on Cement Properties and the Development of Test Procedure for the Evaluation of High Strength Cement. Advances in Cement Research, 15, 1-9. http://dx.doi.org/10.1680/adcr.2003.15.2.67

[7] Haque, M.N. and Kayali, O. (1998) Properties of High-Strength Concrete Using a Fine Fly Ash. Journal of Cement and Concrete Research, 28, 1445-1452. http://dx.doi.org/10.1016/S0008-8846(98)00125-2

[8] Toutanji, H.A. and El-Korchi, T. (1996) Tensile and Compressive Strength of Silica-Fume Cement Pastes and Mortars. Journal of Cement, Concrete and Aggregates, 18, 78-84. http://dx.doi.org/10.1520/CCA10154J

[9] Shannag, M.J. (2000) High Strength Concrete Containing Natural Pozzolan and Silica Fume. Journal of Cement and Concrete Composites, 22, 399-406. http://dx.doi.org/10.1016/S0958-9465(00)00037-8

[10] Cullity, B.D. (1978) Element of X-Ray Diffraction. 2nd Edition, Addision Wesley Publishing Company, Inc.

[11] Awang, H., Mydin, Md.A.O. and Roslan, A.F. (2012) Effect of Additives on Mechanical and Thermal Properties of Lightweight Foamed Concrete. Advances in Applied Science Research, 3, 3326-3338. 